\title{
放射線科における患者転倒の環境要因の分析 一医療安全における科学分析手法の提案一
}

土井 司 $^{1}$ 永吉 誠 $^{2}$ 山谷裕哉 ${ }^{3}$ 山田英司 ${ }^{4} \quad$ 松浦義弘 $^{5} \quad$ 宮西忠史 ${ }^{6}$ 橋田昌弘

\author{
1 社会医療法人高清会高井病院放射線科 \\ 2 大阪大学医学部附属病院医療技術部放射線部門 \\ 3 奈良県立医科大学附属病院中央放射線部 \\ ${ }^{4}$ 大阪市立大学医学部附属病院中央放射線部 \\ ${ }^{5}$ 大阪急性期・総合医療センター医療技術部放射線部門 \\ 6 公益財団法人天理よろづ相談所病院放射線部 \\ ${ }^{7}$ 帝京大学福岡医療技術学部診療放射線学科
}

\section{緒 言}

厚生労働省医政局「医療安全施策の動向」の平成 29 年 1〜 12 月の事故概要によると転倒・転落・誤噁などの 療養上の世話が最も多く $41 \%$ を占め, 次いで治療・処 置の $26.7 \%$, 薬剤 $8.4 \%$, ドレーン・チューブ 6.6\%であ
り，転倒・転落事故が多いことが報告されている ${ }^{1)}$ 。転 倒防止は医療安全施策の最大の課題であるが, とりわ け病棟では環境やシステムを整え, スタッフ教育を充 実させても患者が人間の本質としてもつ「自分のこと は自分でしたい」「人に迷惑をかけたくない」という気

\section{Analysis of the Environmental Factor of a Patient Falls in Department of Radiology - Proposal of Scientific Analysis Method in Patient Safety-}

Tsukasa Doi, ${ }^{1 *}$ Makoto Nagayoshi, ${ }^{2}$ Yuya Yamatani, ${ }^{3}$ Eiji Yamada, ${ }^{4}$ Yoshihiro Matsuura, Tadashi Miyanishi, ${ }^{6}$ and Masahiro Hashida ${ }^{7}$

${ }^{1}$ Clinical Radiology Service, Koseikai Takai Hospital

${ }^{2}$ Department of Medical Technology, Division of Radiology, Osaka University Hospital

${ }^{3}$ Department of Central Radiology, Nara Medical University Hospital

${ }^{4}$ Department of Central Radiology, Osaka City University Hospital

${ }^{5}$ Department of Medical Technology, Division of Radiology, Osaka General Medical Center

${ }^{6}$ Department of Central Radiology, Tenri Hospital

${ }^{7}$ Department of Radiological Technology, Faculty of Fukuoka Medical Technology, Teikyo University

Received June 2, 2019; Revision accepted August 26, 2019

Code No. 610

\section{Summary}

We analyzed 197 fall incidents in the questionnaire survey about the incident that occurred in Department of Radiology. In the past paper about the patient safety, there is no report that evaluated incident data directly. The purpose of this paper is to analyze the factor of the medical incidents using statistical technique scientifically. In this paper, we do not suggest concrete precaution. At first, we found the number of patients (each gender, modality, generation) in the five facilities of the coworker of one week. We found an incident rate from this patient total number, and we normalized data. As a result, we were able to do each risk evaluation because a risk ratio and relative risk degree was found. And, we were able to identify modality and the generation with the significant difference using the testing for differences in population rate. By our analyses, we revealed the chapter which must strengthen safety management.

Key words: patient safety, fall, evaluation, environmental factor 
持ちから行動を起こしてしまった結果であることも多 い.このように転倒事故は, スタッフ教育や環境に起 因する外的要因もさることながら，患者自身に起因す る内的要因も多くあり, 多種多様な要因から発生して いる，転倒事故を防止するための研究やガイドライン は看護分野を中心に報告があり，多くは実態調査を基 に転倒要因の特徵量を抽出することや発生比率を分析 することによって発生リスクと特定し, 注視点や現状 で不足している点を明らかにすることで予防策を論じ ている ${ }^{2 \sim 7)}$. 中には転倒リスクと他の要因との関連性 から統計的手法を用いて評価している論文もあり $り^{8,9)}$, バランス障害の程度によるリスクの評価や処方薬の違 いによるリスクの程度を評価している。これらの報告 は，いずれも転倒を起こした患者が評価対象になって おり，患者の行動機会を母数として扱ったものではな い. しかし米国では, 病院内の転倒防止策が米国医療 研究·品質庁からのガイドラインとして報告され，そ こには転倒比率の算出方法を月ごとの転倒数や 1000

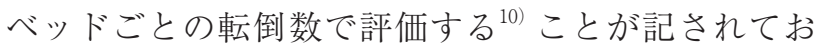
り，転倒リスクを正規化して評価することを提唱して いる.

一方，放射線科の環境を鑑みると，病棟などの患者 管理と異なって目の届くところに患者が存在する場合 がほとんどなので，適合した対策を施せば確実に転倒 事故を減らすことができると考える，既に診療放射線 技師関連では, 医療安全トレーニングの効果をトレー ニング前後の術者の認識を比較した報告 ${ }^{11)} や$ 部署別 のインシデントの傾向を分析し医療安全対策に活用す る報告 ${ }^{12)}$ などが報告され活用されているが，いずれも 医療事故に関連する要因や傾向を直接的に分析してい ないため,リスク評価には不十分である。

このたび，日本放射線技術学会・医療情報部会の中 に2016 2017 年度の 2 年間の時限付きでリスクマネ ジメント班が設立され, 医療安全を科学分野として確 立するための手法を検討することになった。これを受 けて 2017〜2018 年度の学術調査研究班として,「放射 線科検査室内に抢ける患者転倒の環境要因の分析」を テーマに実例を基に分析手法を探ることになった，わ れわれの目的は，医療事故に関する基礎デー夕に対し て, 統計的な手法を用いて傾向や要因を科学的に分析 することであり，具体的な予防策を提案することでは ない，このことを踏まえて本論文では，分析対象デー 夕を放射線科内の転倒事故に絞って, 事故の要因や傾 向を科学的な手法を用いて分析可能かを検討した.

\section{1. 方 法}

\section{1-1 データ収集}

基礎デー夕の収集はアンケート調査とし, Google LLC の Google フォームにて Table 1a に示す質問項 目に対して自由記載を含む選択方式のアンケート フォームを作成し，匿名にて情報を収集した。情報収 集期間は 2017 年 7 10 月とし，日本放射線技術学会 のメーリングリストをはじめ支部や認定機構などを通 じて多くの方に協力を得て情報を収集した.

検討テーマは患者転倒であるが，アンケートの項目 は放射線科内で発生する主なインシデントを対象と し, 発生状況，患者因子，環境因子，操作者因子，障 害の程度，方策につながる六つの大項目からなる 19 項目の情報を収集した(Table 1a)，本論文では転倒に 至る要因について, 男女差, 検査モダリティ, 年齢に 対象を絞って，これらに生じる差の傾向を科学的に要 因として示すことができるかを検討した。 アンケート で得た他の情報の分析は別に報告する.

\section{1-2 データの正規化}

「インシデントが多く発生するから，そのモダリ テイや年代のリスクが高い」とは，一概にはいえない ことから，真に近似できるインシデント率を求めるた めに，班員が所属する5 施設のそれぞれのモダリティ 別および各年代の 1 週間の患者数を調べた。 アンケー 卜に回答のあったインシデントは更に膨大な数の検査 の中で発生した事例であるので, 求めた 1 週間の母数 が大きく変化してもインシデント率として評価するこ とが可能かを男女比のデータを用いてリスク比とオッ ズ比から検証した。なお，リスク比とオッズ比は下記 の式から求めた ${ }^{13}$.

リスク比 $=\frac{(\text { 男性のインシデント数 }) /(\text { 男性患者総数 })}{\text { (女性のインシデント数 }) /(\text { 女性患者総数 })}$

$$
=\frac{\text { 男性のインシデント率 }}{\text { 女性のインシデント率 }}
$$

オッズ比 $=\frac{(\text { 男性のインシデント数 }) /(\text { 女性のインシデント数 })}{(\text { 男性の問題なし検査数 }) /(\text { 女性の問題なし検査数 })}$

$$
=\frac{\text { インシデント数のオッズ }}{=\text { 問題なし検査数のオッズ }}
$$

更に，カイ二乗検定を用いて男女差の有意差検定を 行った. 統計解析には, JMP12.0.3 (SAS Institute Japan，Tokyo, Japan)を使用し， $\mathrm{p}<0.05$ を有意差あり とした ${ }^{14)}$. 
Table 1 A chapter and result of the questionnaire survey

\begin{tabular}{ll}
\hline (a) Factor & \multicolumn{1}{c}{ Question } \\
\hline Occurrences & (1) Event \\
& (2) Place \\
& (3) Time of occurrence \\
& $(4)$ Action of the patient \\
\hline Patient & (5) Gender \\
& (6) Outpatient or inpatient \\
& (7) Age \\
& (8) Clinical department \\
& (9) Background \\
& (10) Patient situation \\
\hline Environmental & (11) Cause of occurrence \\
\hline Operator & (12) Duties experience \\
& (13) Staffs numbers \\
& (14) Care staffs \\
\hline Situation of injury & (15) Result \\
& (16) Risk classification \\
\hline Measures & (17) Cause factor \\
& (18) Foresee \\
& (19) Concreate plan \\
\hline A &
\end{tabular}

A section and chapter of the question by the questionnaire survey

\section{1-3＼cjkstart相対的リスク度による評価}

インシデントの発生数の多いモダリティや年代は, もともとそれに該当する患者数が多いためインシデン 卜数も多くなったことが考えられる。これを正規化す るために患者一人当たりの評価值に換算したのが相対 的リスク度である。この相対的リスク度は，下記の式 から求めた。

相対的リスク度 $=\frac{(\text { 全インシデント数に対する各モダリテイや年代のインシデント発生率 }(\%))}{(\text { 全患者数に対する各モダリテイや年代の存在比 }(\%))}$

\section{1-4 母比率の差の検定 ${ }^{15}$}

比較対象の二つのグループ間の標本比率に有意な差 があるか否かを検証する方法である母比率の差の検定 を用いて，各モダリティと年代による差の評価を行っ た。帰無仮説 $H_{0}$ は「グループ a とグループ b のイン シデント率は等しい」，対立仮設 $H_{1}$ は「グループa と グループ bのインシデント率に差がある」とし, サン プルサイズ $\mathrm{N}$ は標準正規分布 $\mathrm{N}(0,1)$ に従うとした場 合に，両側検定では統計数值表から $Z_{0.025}$ を読み取る と 1.96 となるので，Z>1.96 のときに有意水準 5\%の苯 却域に入り，「帰無仮説 $H_{0}$ を棄却し，対立仮設 $H_{1}$ を 採択する」という結果になる. 片側検定 (有意水準 $10 \%$ ) を採用する場合には， $Z_{0.05}>1.65$ のときにグルー (b)

\begin{tabular}{lcc}
\hline \multicolumn{1}{c}{ Event } & No. & Sub total \\
\hline Fall & 148 & 197 \\
Feel groggy & 40 & \\
Slip & 9 & \\
\hline About the tube & 60 & 176 \\
About the drain & 16 & \\
Nip & 15 & \\
Cut & 12 & \\
etc. & 73 & \\
\hline \multicolumn{1}{c}{ Total } & & \\
\hline
\end{tabular}

Classification of the questionnaire outcome
プ間のインシデント率に有意な差があるとした。検定 統計量 $\mathrm{Z}$ は, グループ $\mathrm{a}$ の標本比率を $\mathrm{P}_{\mathrm{a}}$, サンプルサ イズを $\mathrm{N}_{\mathrm{a}}$, グループ b の標本比率を $\mathrm{P}_{\mathrm{b}}$, サンプルサ イズを $\mathrm{N}_{\mathrm{b}}$ ，二つの標本比率を一つにまとめた全標本 比率を Pとして，下記の式から求めた ${ }^{16)}$.

検定統計量 $Z=\frac{\mathrm{P}_{\mathrm{a}}-\mathrm{P}_{\mathrm{b}}}{\sqrt{\mathrm{P}(1-\mathrm{P})\left(\left(1 / \mathrm{N}_{\mathrm{a}}\right)+\left(1 / \mathrm{N}_{\mathrm{b}}\right)\right)}}$

$$
\mathrm{P}=\frac{\mathrm{N}_{\mathrm{a}} \mathrm{P}_{\mathrm{a}}+\mathrm{N}_{\mathrm{b}} \mathrm{P}_{\mathrm{b}}}{\mathrm{N}_{\mathrm{a}}+\mathrm{N}_{\mathrm{b}}}
$$

\section{2. 結 果}

\section{2-1 データ収集結果}

アンケートには 373 件の回答があった。 そのうち, 転倒 148 件，ふらつき 40 件，つまずき 9 件の 197 件を 今回の分析対象とした(Table 1b)。197 件のモダリ ティ別の内訳は，一般撮影が 115 件と抜きん出て多く 全インシデントの $58.4 \%$ を占め, 次いで magnetic resonance imaging (MRI)の 24 件(全インシデントの $12.2 \%), X$ 線 TV, 核医学検査, 放射線治療の 10 件 (各々全インシデントの $5.1 \%$ ) だった (Fig. 1a)。年代 別では， 70 歳代が最も多く 77 件で全インシデントの $39.1 \%$ を占め, 次いで 60 歳代の 42 件(全インシデント の $21.3 \%$ ), 80 歳代の 32 件 (同 16.2\%), 50 歳代の 17 

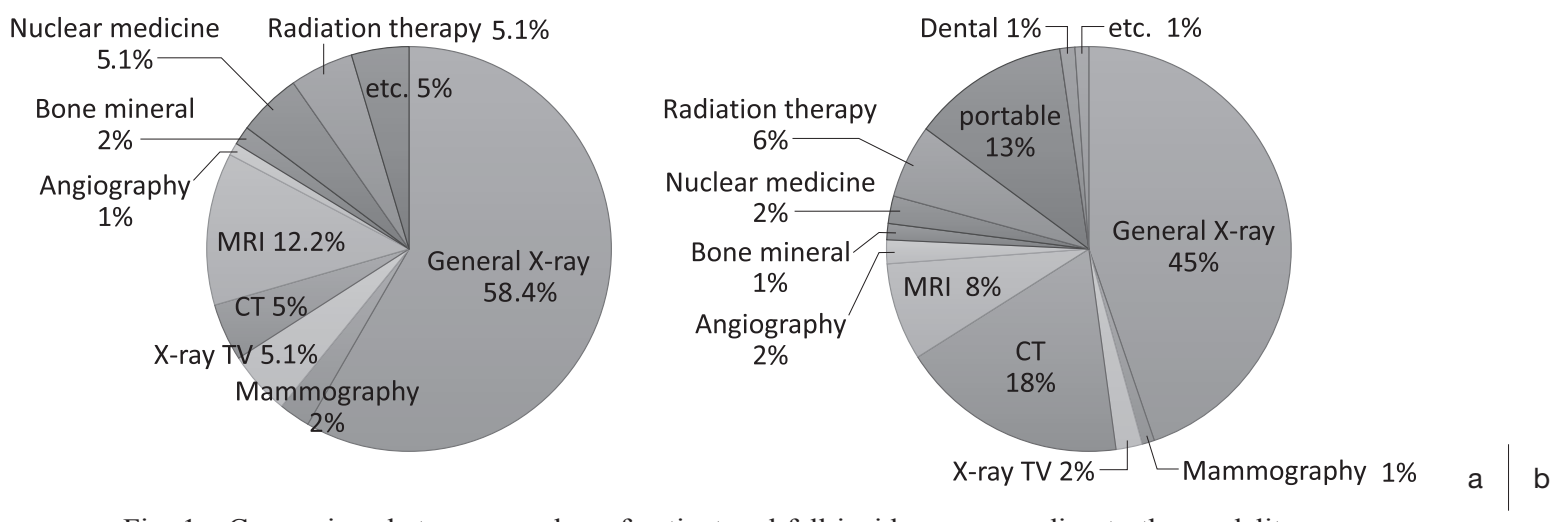

Fig. 1 Comparison between number of patient and fall incidences according to the modality.

(a) The ratio of the patient according to the modality for the number of all falls

(b) The ratio of the patient according to the modality for the total number of patients
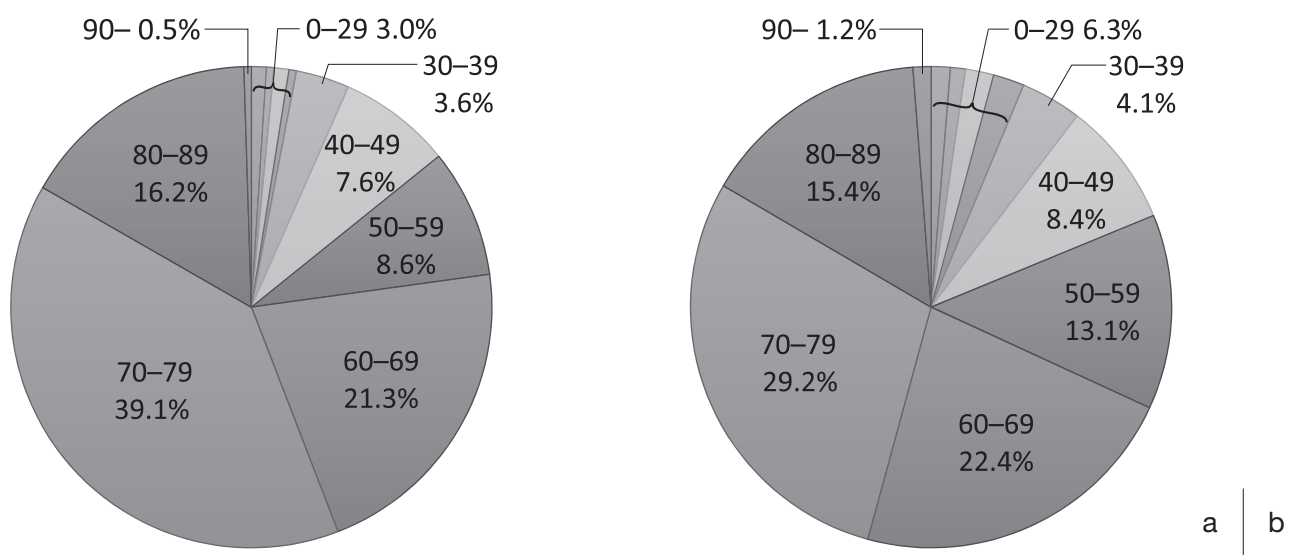

Fig. 2 Comparison between the rate of patient and the rate of fall each generation.

(a) The ratio of the patient according to the generation for the number of all falls

(b) The ratio of the patient according to the generation for the total number of patients

件(同 8.6\%)だった(Fig. 2a)，男女別では，男性が 116 件，女性が 81 件と男性のインシデントが約 40\%多 かった(Table 2).

\section{2-2 データの正規化と男女比}

班員が所属する五つの施設のモダリティ別，年代 別, 男女別の 1 週間の検查数を調べ, それを平均して インシデント率を求めるための母数とした. Table 3 は，モダリティ別の各施設の検査数である。最も多い のが一般撮影の 1 週間当たり約 1700 人で全検查数の 45\%を占め, その次に多いのが computed tomography $(\mathrm{CT})$ の約 690 人で $18 \%$, MRI は約 300 人で $8 \%$, 放射線治療は約 225 人で $6 \%, X$ 線 TV や核医学検査 は約 85 人で $2 \%$ だった(Fig. 1b).

年代別の患者の比率は, 70 歳代が全患者数の $29.2 \%$ を占め最も多く, 次いで 60 歳代の $22.4 \%, 80$ 歳代の 15.4\%，50 歳代の $13.1 \% の$ 順で多かった (Fig. 2b).
男女比では，転倒の多い男性の方が 2081 人と 1 週 間当たりの患者数も多く，女性の 1824 人に比べて 13\%多かった。男性の 1 週間のインシデント率は $5.57 \times 10^{-2}$, 女性は $4.44 \times 10^{-2}$ となった。 母数を 1 年に増 やすと男性のインシデント率は $0.98 \times 10^{-3}$, 女性は $0.77 \times 10^{-3}$ と約 57 分の 1 になるが, リスク比は母数の 大きさによらず男性が女性の 1.26 倍だった。オッズ 比も, 転倒数のオッズと問題なく終えた検査数のオッ ズの比から求めたのでリスク比と同様に母数の大きさ によって值は変わらず，男性が女性の約 1.27 倍になっ た。しかし，カイ二乗検定による男女の比較に有意差 はなかった(Table 4).

\section{2-3＼cjkstart相対的リスク度による評価}

インシデントの発生数の整合性をとるために, モダ リティそのものの患者数に対するインシデントの発生 率を求めた結果，一般撮影のインシデントが全体の 
Table 2 Classification of the reply about the fall

\begin{tabular}{lc}
\hline \multicolumn{1}{c}{ Modality } & No. \\
\hline General X-ray & 115 \\
Mammography & 5 \\
X-ray TV & 10 \\
CT & 9 \\
MRI & 24 \\
Angiography & 2 \\
Bone mineral measure- & 3 \\
ment & 10 \\
Nuclear medicine & 10 \\
Radiation therapy & 9 \\
etc. & 197 \\
\hline
\end{tabular}

The number of the incidents by the modality (b)

\begin{tabular}{cc}
\hline \hline Age & No. \\
\hline$<3$ & 2 \\
$3-9$ & 1 \\
$10-19$ & 2 \\
$20-29$ & 1 \\
$30-39$ & 7 \\
$40-49$ & 15 \\
$50-59$ & 17 \\
$60-69$ & 42 \\
$70-79$ & 77 \\
$80-89$ & 32 \\
$90 \leq$ & 1 \\
\hline Total & 197 \\
\hline
\end{tabular}

The number of the incidents by the generation (c)

\begin{tabular}{lc}
\hline \hline Gender & No. \\
\hline Male & 116 \\
Female & 81 \\
\hline
\end{tabular}

The number of the incidents by the gender gap

Table 3 The number of patients according to the modality of 1 week in each facility

\begin{tabular}{lcccccccc}
\hline \hline \multicolumn{1}{c}{ Modality } & Hp.1 & Hp.2 & Hp.3 & Hp.4 & Hp.5 & $\begin{array}{c}\text { Weekly } \\
\text { total }\end{array}$ & $\begin{array}{c}\text { Weekly } \\
\text { average }\end{array}$ & $\begin{array}{c}\text { Annual number } \\
\text { of patient }\end{array}$ \\
\hline General X-ray & 1718 & 1963 & 1864 & 1447 & 1511 & 8503 & 1700.6 & 88686 \\
Mammography & 88 & 9 & 39 & 35 & 16 & 187 & 37.4 & 1950 \\
X-ray TV & 173 & 69 & 80 & 48 & 31 & 401 & 80.2 & 4182 \\
CT & 642 & 762 & 674 & 663 & 707 & 3448 & 689.6 & 35962 \\
MRI & 463 & 220 & 250 & 253 & 293 & 1479 & 295.8 & 15426 \\
Angiography & 52 & 94 & 64 & 67 & 90 & 367 & 73.4 & 3828 \\
Bone mineral measurement & 92 & 30 & 74 & 21 & 28 & 245 & 49.0 & 2555 \\
Nuclear medicine & 98 & 58 & 128 & 56 & 80 & 420 & 84.0 & 4380 \\
Radiation therapy & & 185 & 312 & 174 & & 671 & 223.7 & 11664 \\
etc. & 41 & 14 & 207 & 59 & 108 & 429 & 85.8 & 4474 \\
\hline \multicolumn{1}{c}{ Total } & 3741 & 4037 & 4413 & 3256 & 3302 & 18542 & 3839.3 & 200186 \\
\hline
\end{tabular}

I assumed the average of five facilities the number of patients of 1 week

$58.4 \%$ あるるのに対して患者数が $44.8 \%$ のため，相対 的リスク度は 1.30 だった。、ンモグラフィやX 線 $\mathrm{TV}$ ，核医学検査では患者比率が少ない割にインシデ ント比率が高く 2.0 を超えた。逆にCT は患者比率が $18.2 \%$ と高いにもかかわらずインシデント比率が $4.6 \%$ と低く，相対的リスク度は 0.25 となった。 MRI は患者比率が $7.8 \%$ でインシデント比率が $12.2 \%$ とな り，相対的リスク度は 1.56 だった(Table 5)。

年代別では, 70 歳代がインシデント数と患者数とも 最も多く，インシデント比率が患者比率を上回り相対 リスク度は 1.34 となった。次いで 80 歳代のインシデ ント比率が患者比率わずかに上回り相対リスク度は 1.05 となった。それ以外は 1 を下回り, 60 歳代は 0.95 , 40 歳代 0.91, 30 歳代 0.87 の順になった (Table 6).

\section{2-4 母比率の差の検定}

モダリテイ別㧍よび年代別のインシデント率を年間 の患者概数に対するインシデント数として求めた (Table 7). その各々を母比率の差の検定を用いて有 意差を求めた。モダリティ別では，CT が血管撮影を 除くすべてのモダリテイに比ベインシデント率が有意 に少なかった。 それ以外では，マンモグラフィと血管 撮影・放射線治療の比較，X 線 TV と血管撮影・放射 線治療の比較, 核医学検查と血管撮影の比較に有意差 があった，しかし，放射線治療とマンモグラフィ・X 線 TV のリスク比が 2.78〜2.97 倍で有意な差があった のに対して，X線 TVが放射線治療に対してリスク比 が 2.8 倍, MRIが血管撮影に対してリスク比が 3 倍で 
Table 4 Change of a risk ratio and the odds ratio for the number of patients (parameter)

\begin{tabular}{|c|c|c|c|c|c|c|c|}
\hline Gender & Fall & No problem & Total & Incident rate & \multicolumn{3}{|c|}{ Male/Female } \\
\hline Male & 116 & 1965 & 2081 & $5.57 \mathrm{E}-02$ & \multirow{2}{*}{ NS } & Risk ratio & 1.255 \\
\hline Female & 81 & 1743 & 1824 & 4.44E-02 & & Odds ratio & 1.270 \\
\hline Odds & 1.43 & 1.13 & & & & & \\
\hline
\end{tabular}

1 week

\begin{tabular}{|c|c|c|c|c|c|c|c|}
\hline Gender & Fall & No problem & Total & Incident rat & & \multicolumn{2}{|c|}{ Male/Female } \\
\hline Male & 116 & 9825 & 9941 & $1.17 \mathrm{E}-02$ & \multirow{2}{*}{ NS } & Risk ratio & 1.267 \\
\hline Female & 81 & 8717 & 8798 & $0.92 \mathrm{E}-02$ & & Odds ratio & 1.271 \\
\hline Odds & 1.43 & 1.13 & & & & & \\
\hline
\end{tabular}

1 month $(1$ week $\times 5)$

\begin{tabular}{lcccccc}
\hline \hline Gender & Fall & No problem & Total & Incident rate & & Male/Female \\
\hline Male & 116 & 117900 & 118016 & $0.98 \mathrm{E}-03$ & Risk ratio & 1.270 \\
Female & 81 & 104604 & 104685 & $0.77 \mathrm{E}-03$ & NS & Odds ratio \\
Odds & 1.43 & 1.13 & & & & \\
\hline
\end{tabular}

1 year $(1$ month $\times 12)$

Table 5 Relative risk level of each modality

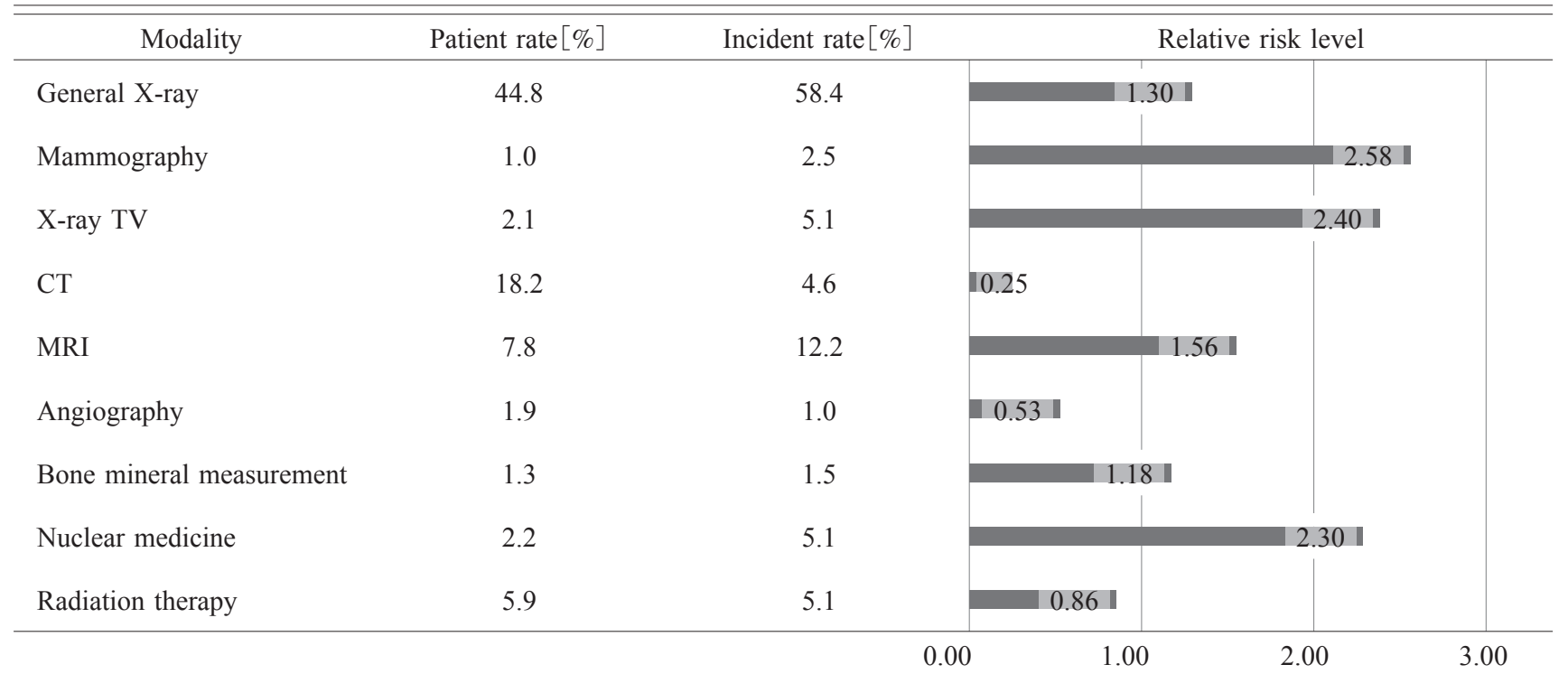

あっても有意差はなかった(Table 7a).

年代別の評価では, 両側検定を用いると70 歳代が 50 歳代に比べて有意に多いと検定されただけであっ た.しかし片側検定を行うと, 70 歳代が 60 歳代や 20 歳代，20歳以下に比べて有意に多くなった(Table 7b).

\section{3. 考 察}

\section{3-1 他の報告との比較}

看護師による転倒に関する先行研究では, 転倒に至 る患者の行動, 年齢, 認知症を含む認識力, 運動機能, 患者心理などを分析した結果, 転倒要因として排泄行 動に関するものが半数以上を占め, 患者自身の運動能
力の過信からの発生も多いとの報告がある。また，ア ルツハイマー型やレビー小体型など認知症の種類に よっても転倒リスクが異なり, 記憶障害や視空間障害 のある認知症の患者には生活環境を改善するために, 多職種チームによる転倒予防や患者の状況に合わせた 予防策の構築を推奨している, ${ }^{4,5,6)}$. 理学療法士は, バ ランス能力評価から姿勢反応と歩行安定性の低下が転 倒を招くとし，転倒予防には散歩などによる機能低下 の抑止策が転倒予防につながるとしている 薬剂師は, 年齢や体重, 性別は転倒のリスク因子では なく, 脳血管疾患などの身体的要因と, 抗精神薬剤の 一種であるゾルビデム酒石酸塩とカルシウム受容体拮 
Table 6 Relative risk level of each generation

\begin{tabular}{|c|c|c|c|c|}
\hline Age & Patient rate $[\%]$ & Incident rate $[\%]$ & \multicolumn{2}{|c|}{ Relative development risk } \\
\hline$<3$ & 1.3 & 1.0 & 0.79 & \\
\hline $3-9$ & 1.0 & 0.5 & 0.52 & \\
\hline $10-19$ & 1.9 & 1.0 & 0.53 & \\
\hline $20-29$ & 2.1 & 0.5 & 0.25 & \\
\hline $30-39$ & 4.1 & 3.6 & 0.87 & \\
\hline $40-49$ & 8.4 & 7.6 & 0.91 & \\
\hline $50-59$ & 13.1 & 8.6 & 0.66 & \\
\hline $60-69$ & 22.4 & 21.3 & 0.95 & \\
\hline $70-79$ & 29.2 & 39.1 & & 1.34 \\
\hline $80-89$ & 15.4 & 16.2 & 1.05 & \\
\hline $90 \leq$ & 1.2 & 0.5 & 0.43 & \\
\hline
\end{tabular}

Table 7 Evaluation of the testing for differences in population rate using the incident rate

(a)

\begin{tabular}{cccc}
\hline \hline Modality & Incident No. & Patient No./year & Incident rate \\
\hline General X-ray & 115 & 88686 & $1.30 \mathrm{E}-03$ \\
Mammography & 5 & 1950 & $2.56 \mathrm{E}-03$ \\
X-ray TV & 10 & 4182 & $2.39 \mathrm{E}-03$ \\
CT & 9 & 35962 & $0.25 \mathrm{E}-03$ \\
MRI & 24 & 15426 & $1.56 \mathrm{E}-03$ \\
Angiography & 2 & 3828 & $0.52 \mathrm{E}-03$ \\
Bone mineral measurement & 3 & 2555 & $1.17 \mathrm{E}-03$ \\
Nuclear medicine & 10 & 4380 & $2.28 \mathrm{E}-03$ \\
Radiation therapy & 10 & 11664 & $0.86 \mathrm{E}-03$ \\
\hline
\end{tabular}

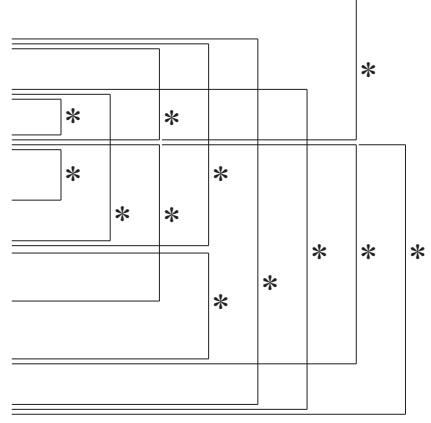

Significant difference test for every modality

(b)

\begin{tabular}{|c|c|c|c|}
\hline Age & Incident No. & Patient No./year & Incident rate \\
\hline$<20$ & 5 & 7750 & $0.65 \mathrm{E}-03$ \\
\hline $20-29$ & 1 & 3810 & $0.26 \mathrm{E}-03$ \\
\hline $30-39$ & 7 & 7600 & $0.92 \mathrm{E}-03$ \\
\hline $40-49$ & 15 & 15520 & $0.97 \mathrm{E}-03$ \\
\hline $50-59$ & 17 & 24220 & $0.70 \mathrm{E}-03$ \\
\hline $60-69$ & 42 & 41610 & $1.01 \mathrm{E}-03$ \\
\hline $70-79$ & 77 & 54150 & $1.42 \mathrm{E}-03$ \\
\hline $80-89$ & 32 & 28560 & $1.12 \mathrm{E}-03$ \\
\hline $90 \leq$ & 1 & 2200 & $0.45 \mathrm{E}-04$ \\
\hline
\end{tabular}

Significant difference test for every generation

$*>1.96$

$※>1.65$ 
抗薬が外因性のリスク因子だと報告している9 。これ らの中にも統計的手法を用いて有意差を導いている報 告もあるが，すべてインシデント発生後に患者の背景 を分類して比較したものである.

転倒のように比較対象の母数となる患者数が不特定 大多数である場合に，患者のどのような行動が転倒を 誘発するリスクであるかの実数が掴めていない現状が ある。例えば, 認知症においても転倒対象となったア ルッハイマー型の患者とレビー小体型の患者の人数が わかれば，もっと詳細な分析ができたと考える。唯 一, 米国医療研究・品質庁のガイドラインが 1000 ベッ ドに対する転倒数を転倒率としているが，その背景ご とに要因を分析するのは困難である ${ }^{10)}$.

\section{3-2 リスク比とオッズ比}

幸いにして放射線科では，今回比較対象とした性 別, モダリティ, 年齢ごとの被検者となる患者数が求 まるため，それらを母数としたインシデント率として 評価することができた。 そして、リスク比やオッズ比 で評価することで，母数が変化しても值が変わらない ことが検証できた (Table 4). しかし，データのサン プリング方法が，コホート研究であるかケースコント ロール研究かが見極めにくいため, 転倒のリスク比に おいて男性が女性に比べて 1.26 倍高いと明言できな いのだと考える ${ }^{13)}$ ．また，オッズ比とリスク比が近似 な值になったのは，イベントの発生確率が非常に低い のが原因で ${ }^{17)}$ ，カイ二乗検定で帰無仮説を棄却できず 有意差が認められなかったことから，「男性の方が転 倒のリスクは高いが, 女性に比べて有意に高いとはい えない」という結果になった。

\section{3-3 相対的リスク度による評価}

「インシデントが多いからそのモダリティやその年 代のリスクが高い」という錯覚を払拭するために，モ ダリティや年代そのもののリスク度を表現することを 目的に相対的リスク度を求めた。患者数が多くなると インシデントが多くなるのが当然であるが，CTなど 検査数が多いにもかかわらずインシデントが少ない検 査や, マンモグラフィやX線 TV, 核医学のように患 者数が比較的少ないのにもかかわらずインシデント率 の高いモダリティがあった(Table 5)。これは, マン モグラフィ時の圧迫の痛みによる身体の不調の誘発, $\mathrm{X}$ 線 TV や核医学検査の検査台への昇降時の段差や スリッパによる歩行などが原因になっているのだと考 える，また，MRIでは更衣時の転倒の報告が多くあ り，患者が一人になるときの安全対策の構築が望まれ
る。逆にCTでは, 独歩での来室もしくは重症の場合 は周辺にスタッフがいることが多いので，検査数が多 い割には転倒事例が少ないのだと考える (Table 5).

年齢別では, 70 歳代が来院される人数が多い以上に 転倒事例が多く, リスク度も 1.34 と他の年代に比べて 極めて高い值となった。これは, 病気を多く発症する 年代であることや，これまで元気だった生活習慣から の自意識と身体機能に乘離を起こすからだと考える. 逆に 80 歳代になると自意識と身体機能が適合してく るのとスタッフが相応に注意を払うので, 70 歳代より 低くなったと考える．30～60 歳代は，術後や不注意な ど他の要因が考えられ，年代に関しては 70 歳代に最 も気をつけるべきであることが明確になった(Table 6).

\section{3-4 母比率の差の検定}

放射線科で発生する転倒は, どちらかというと稀な 事象でありインシデントが発生する回数はポアソン分 布に従う。しかし今回は膨大な検査数を母数としてい るので, 中心極限定理によって正規分布に収束すると して母比率の差の検定を適合させた。検定の結果, モ ダリティ別においては,「CT が極めて転倒事故の少な いモダリティである」ことが明確になった以外に，相 対的リスク度の高かったマンモグラフィやX $\mathrm{X}$ 線 TV, 核医学検査と他のモダリティとの間には明確な有意な 差がなかった。リスク比に大きな差があると当然有意 な差がでるが, インシデント数が少なくインシデント 比が極めて小さい場合には, 有意な差として検定しに くくなると考える。したがって，それぞれ相対的リス ク度の大きいモダリティや小さいモダリティを挙げる ことは可能であっても, 有意差をもって示すことので きるモダリティは限定されることがわかった(Table 7a).

同様に年代別では，両側検定で有意差があると示さ れたのは, 70 歳代と 50 歳代のみでありリスク比は約 2 倍だった。それ以外の年齢では $\mathrm{p}<0.05$ の条件で有 意な差を認めなかった(Table 7b)，このことは，患者 数も多い 70 歳代に最も注意を払う必要があるが, 臨 床では年齢要因よりもそのときの患者の背景や状況を 読み取り，患者からひとときも目を離すことなく，起 こりえる不測の事態を回避できるように普段から訓練 しておく必要があることを示している，安田らの検 証 $^{11)}$ や日本放射線技術学会近畿支部が作成した危険 予知トレーニング18) などを参考に実践能力を各人が 身に付けることが望まれる。

\section{3-5 本論文のまとめと課題}

橋田らが分析に用いた同一施設放射線科のインシデ 
ントレポートは, 11 年間に 202 件で, そのうち転倒関 連が $10 \%$ の約 20 件であった ${ }^{12)}$. 今回分析に用いた 196 件というデー夕数を考えると，もっと多くの事例 があると予測できる反面，施設によってはほとんど発 生しない事例であるともいえる。また，デー夕提供に 協力していただいたモダリテイに偏りがあることも考 えられ，今回の事故事例が氷山の一角であることを認 識しなければない。.また, 評価の母数とした 1 週間の 患者数は大規模施設のものであり, 国内の多くを占め る 100３00 床規模の患者分布とは異なっている可能 性もある。今回の分析によって，一般撮影より MRI やマンモグラフィ, X 線 TV, 核医学検査のリスクが 高く, 男性の 70 歳代が最も要注意であることが明ら かになったが, このことによって, それ以外のモダリ ティや年齢に対して注意力を低下させてよい訳はな く, この結果は, 更に注意力を増すことを認識させる ものとして活用していただきたい.今回の評価では, 転倒のインシデントレベルを区別せずリスク比を求め たが，障害の程度を評価するリスク度を加味すると， 重大な事故が発生しやすいモダリティや年代を特定す ることができ, 更に詳細なリスク度が求まる可能性が ある。

\section{4. 結 語}

アンケート調査で収集した 197 件の転倒関連のイン シデントを分析するにあたって, 性差, モダリティ, 年齢の患者総数 (母数)を求めることによって正規化を
罒ることで，それぞれの項目ごとのリスク比やオッズ 比, 相対的リスク度を求元ことができた。 リスク比 および相対的リスク度によってリスクの評価が可能に なり，母比率の差の検定を用いることによって有意に 差のあるモダリティや年代を特定することができた. このように，それぞれの項目に対するインシデント率 を求めることによって, 医療安全に関する評価を科学 的に分析することが可能であることを示すことができ た。

この成果によって, より注視すべきモダリティや年 齢, 性差と発生要因が明確になり, 加えて患者の心情 を汲み取れるようになれば，事故を未然に防ぐ危険予 知行動の動機付けにつながると考える.

\section{謝 辞}

本論文は，日本放射線技術学会の 2017～2018 年度 の学術調查研究班「放射線科検査室内に招ける患者転 倒の環境要因の分析」として活動した成果の一部であ る. 要旨は, 日本放射線技術学会第 46 回秋季学術大 会 (2018 年 10 月, 仙台)にて発表した。な抢本研究の アンケート調査は, 大阪大学医学部附属病院の観察研 究倫理審査委員会の承認 (承認番号 16531-2) を得て実 施した.

\section{利益相反}

筆頭著者および共著者全員に開示すべき利益相反は ない.

\section{参考文献}

1）日本医療機能評価機構 医療事故防止事業部 医療事故情 報収集等事業 第 52 回報告書 (2017 年 10 月～12 月). 2018 http://www.med-safe.jp/pdf/report_52.pdf(2019/4/15 確 認).

2) Falls: Assessment and prevention of falls in older people. National Institute for Health and Care Excellence. UK. 2013.

3) Hempel S, Newberry S, Wang Z, et al. Hospital fall prevention: a systematic review of implementation, components, adherence, and effectiveness. J Am Geriatr Soc 2013; 61(4): 483-494.

4）松田恵美子. 急性期病院における入院患者の転倒・転落 の現状と今後の課題一転倒・転落事故報告書の実態調査 より一. 徳島赤十字病医誌 2010; 15(1): 139-143.

5）鈴木みずえ. 認知症高齢者の転倒予防：認知症高齢者の 視点からの転倒予防のエビデンスと実践. 日転倒予会誌 2016; 2(3): 3-9.

6）山田楼子, 高島幹子, 佐藤幸美, 他. 転倒·転落に伴うイ ンシデント事例の検討と対策一発生構造に基づいた分類 法を用いて一． 秋田大医研科紀要 2010; 18(2): 144-150.

7）林 泰史. 第 49 回日本老年医学会学術集会記録〈Meet the Expert〉高齢者の転倒防止. 日老医誌 2007; 44(5): 591594.
8) 越前谷友樹, 秋月千典. Mini-Balance Evaluation System Test による転倒患者のバランス障害因子の検討. 理療科 2014; 29(5): 693-697.

9）小園亜希, 諫見圭祐, 塩田喜美子, 他. 入院患者における 転倒・転落と処方箋の関連性調査. YAKUGAKU ZASSHI 2016; 136(5): 769-776.

10) Preventing Falls in Hospitals 5. How do you measure fall rates and fall prevention practices? Agency for Healthcare Research and Quality. https://www.ahrq.gov/professionals/systems/hospital/ fallpxtoolkit/fallpxtk5.html(2019/4/17 確認).

11）安田光慶, 加藤京一, 内山裕史, 他. 放射線部の医療安全 における危険予知トレーニング (KYT) 導入の効果. 日放 技学誌 2013; 69(7): 788-794.

12）橋田昌弘, 白石順二. 診療放射線技師の業務に関連した インシデントレポート一過去 10 年分の解析結果一. 日放 技学誌 2015; 71(2): 99-107.

13）統計分析研究所 株式会社アイスタット.リスク比とオッ ズ比. https://istat.co.jp/sk_commentary/risk_odds (2019.5.1 確認).

14）統計 WEB. BellCurve. 25-5. 独立性の検定. https://bell curve.jp/statistics/course/9496.html(2019.5.1 確認). 
15）統計 WEB. BellCurve. 25-7. 母比率の差の検定． https:// bellcurve.jp/statistics/course/18227.html(2019.4.4 確認).

16）圭井 司, 徳永真司, 田畑洋二. 医療安全対策の有効性を 視覚化する一稀な事象に対する評価方法の提案一. 日放 技学誌 2019; 75(11): 1270-1276.
17) 大林 準.ロジスティック回帰分析と傾向スコア (propensity score)解析. 天理医紀 2016; 19(2): 71-79.

18）日本放射線技術学会 編。動画で見る医療安全放射線部 門の危険予知トレーニング(叢書)。京都; 日本放射線技 術学会出版委員会, 2015. 